\title{
Src Family Kinases Are Involved in EphA Receptor-Mediated Retinal Axon Guidance
}

\author{
Bernd Knöll and Uwe Drescher \\ Medical Research Council Centre for Developmental Neurobiology, King’s College London, London SE1 1UL, United Kingdom
}

\begin{abstract}
EphA receptor tyrosine kinases and their ephrin ligands play important roles in wiring of the developing nervous system. We have investigated here the function of Src family kinases (SFKs) in the retinotectal projection to dissect the signaling pathways by which EphA receptors control actin/microtubule rearrangements that underlie growth cone guidance and collapse. Both EphAs and SFKs are expressed broadly in retinal growth cones, and SFKs are recruited to EphA receptors after ephrinA stimulation. In the stripe and growth cone collapse assays we observe an abolition of EphA-mediated repulsion after inhibiting SFKs, either pharmacologically or enzymatically via electroporation-mediated overexpression of the SFK inhibitor Csk. In addition, we identify cortactin and the RhoGEF ephexin, which interact with EphA receptors in retinal axons, as targets of SFK-dependent tyrosine phosphorylation. In sum, our data suggest an important role of SFKs as downstream signaling molecules in EphA receptor-mediated repulsive axon guidance.
\end{abstract}

Key words: retinotectal projection; axon guidance; Eph family; Src family kinase; intracellular signaling; actin cytoskeleton

\section{Introduction}

The roles of the Eph family of receptor tyrosine kinases and their membrane-bound ephrin ligands in guiding axons to their distant targets have been studied intensively, for example in topographically organized sensory systems such as the retinotectal projection (Drescher et al., 1997; Flanagan and Vanderhaeghen, 1998; Wilkinson, 2000; Knöll and Drescher, 2002; Kullander and Klein, 2002; McLaughlin et al., 2003). Activation of EphA receptors triggers a repulsive response, ultimately leading to a turning or a collapse of the growth cone (Weinl et al., 2003). Analysis of the underlying signal transduction network has led to the identification of several signaling molecules that link EphA receptor activation and actin/microtubule cytoskeletal dynamics. Examples of these are MAP kinases, PI-3 kinase, p190rhoGAP/rasGAP, abl, phospholipase $\mathrm{C} \gamma$, grb2, ephexin [a RhoGEF (guanine nucleotide exchange factor) controlling RhoA], and Src family kinases (SFKs) (Kullander and Klein, 2002; Guan and Rao, 2003).

Members of the Src family (for review, see Thomas and Brugge, 1997; Abram and Courtneidge, 2000; Frame et al., 2002) bind to the juxtamembrane region of Eph receptors via two well conserved phosphorylated tyrosine residues (Ellis et al., 1996; Zisch et al., 1998). After binding, SFKs in turn tyrosinephosphorylate and modulate the function and/or binding properties of a plethora of signaling molecules such as components of integrin-containing adhesion complexes, neural Wiskott Aldrich

Received March 17, 2004; revised May 25, 2004; accepted May 25, 2004.

This work was supported by the Wellcome Trust and a fellowship from the Deutsche Forschungsgemeinschaft to B.K. We are grateful to Britta Eickholt, Philipp Gordon-Weeks, Adrian Pini, and Rosemary Drescher for valuable comments on this manuscript. We thank M. Greenberg for antibodies and J. Gilthorpe for expression constructs.

Correspondence should be addressed to Uwe Drescher, Medical Research Council Centre for Developmental Neurobiology, King's College London, New Hunt's House, Guy's Hospital Campus, London SE1 1UL, UK. E-mail: uwe.drescher@kcl.ac.uk.

DOI:10.1523/JNEUROSCI.0985-04.2004

Copyright $\odot 2004$ Society for Neuroscience $\quad$ 0270-6474/04/246248-10\$15.00/0
Syndrome protein (N-WASP) and cortactin, activators of the Arp2/3 complex, and p190rhoGAP, an inhibitor of RhoA (Abram and Courtneidge, 2000).

In rodents eight different SFKs have been identified (Thomas and Brugge, 1997), which are functionally highly redundant (Stein et al., 1994; Klinghoffer et al., 1999). Four of these (Lyn, Fyn, Yes, and Src) are expressed widely in the nervous system (Thomas and Brugge, 1997), where functions have been assigned to them in neurite outgrowth (Beggs et al., 1994; Ignelzi et al., 1994; Suetsugu et al., 2002), axon fasciculation (Morse et al., 1998), and modulation of synaptic plasticity (Takasu et al., 2002). A full picture of the roles of SFKs in vivo is difficult to obtain because of their apparent redundancy, on the one hand, and the early death of $\mathrm{src}^{-1-}, \mathrm{fyn}^{-1-}$, yes ${ }^{-1-}$ triple mutants at embryonic day 9.5 (E9.5) on the other hand (Klinghoffer et al., 1999).

SFK activity is switched off by Csk (C-terminal Src kinase) (Thomas and Brugge, 1997). This inhibition is part of an inhibitory feedback loop in which activated SFKs phosphorylate the lipid raft-associated protein $\mathrm{Cbp}$, which then recruits Csk to the membrane (Cary and Cooper, 2000) to phosphorylate a C-terminal tyrosine residue conserved in all SFK members (Thomas and Brugge, 1997). Tyrosine phosphorylation at this position forces SFKs into an inactive conformation in which this residue is bound intramolecularly to its own $\mathrm{SH} 2$ domain, thereby preventing its interaction with target proteins. The role of Csk in inhibiting SFKs is highlighted in $c s k^{-/}$mouse embryos, which show a strong increase in SFK activity (Imamoto and Soriano, 1993; Nada et al., 1993).

The importance of tyrosine phosphorylation in axon guidance is well known from studies demonstrating axon-pathfinding defects after inhibition of tyrosine phosphorylation in vivo (Worley and Holt, 1996; Robles et al., 2003). Here we identify SFKs as important components of EphA receptor-mediated axon guidance. Inhibiting SFK-mediated tyrosine phosphorylation, either 
pharmacologically or enzymatically by overexpressing Csk in retinal axons, abolishes EphA-mediated repulsion in stripe and growth cone collapse assays. The target proteins of SFK tyrosine phosphorylation, which interact with EphA receptors in the retina, have been identified as the RhoGEF ephexin and cortactin.

\section{Materials and Methods}

Immunohistochemistry. E6-E7 chicken retinal explants grown in F12 medium were fixed with $0.25 \%$ glutaraldehyde $/ 0.5 \%$ formaldehyde and washed with PBS; free aldehyde groups were quenched by using $1 \%$ glycine/PBS for $20 \mathrm{~min}$, followed by washing. After being blocked with $2 \% \mathrm{BSA} / \mathrm{PBS}$, the cultures were incubated with hybridoma supernatant containing monoclonal anti-EphA4 antibody (Connor et al., 1998). After a rinsing, secondary antibodies (goat anti-mouse Alexa 594; 1:1000 in block) were applied for $1 \mathrm{hr}$. After being washed with PBS, the cultures were permeabilized with $0.1 \%$ Triton X-100/PBS, blocked, incubated with rabbit anti-pan-Src antibody (s.c.-18, Santa Cruz Biotechnology, Santa Cruz, CA), and detected with goat anti-rabbit Alexa Fluor 488 antibodies. Controls omitting the primary antibodies resulted only in background signals.

Cell culture. Human embryonic kidney 293 (HEK293) and Src, Yes, Fyn (SYF cells) (Klinghoffer et al., 1999) were kept in DMEM/10\% FCS and transfected with a standard calcium-phosphate method. For serum starvation the cells were kept in $0.5 \%$ FCS/DMEM for $\geq 16 \mathrm{hr}$. Incubation with 2-7.5 $\mu \mathrm{M}$ PP2 or PP3 (Calbiochem, La Jolla, CA) lasted $30 \mathrm{~min}$ in $0.5 \%$ FCS/DMEM. Subsequently, the cells were stimulated for another $30 \mathrm{~min}$ with $1 \mu \mathrm{g} / \mathrm{ml}$ ephrinA5-Fc (preclustered for $30 \mathrm{~min}$ with 10 $\mu \mathrm{g} / \mathrm{ml}$ goat anti-human IgG; Sigma, St. Louis, MO) in the presence of $\mathrm{PP} 2 / \mathrm{PP} 3$. Controls were incubated with preclustered Fc protein alone.

Nasal or temporal thirds of three to four retinas of E7-E8 chicken embryos were collected in HBSS and incubated for 15 min with $5 \mu \mathrm{M}$ PP2/PP3 or $2.5 \mu \mathrm{M} \mathrm{SU} 6656$ (Calbiochem) in HBSS at $37^{\circ} \mathrm{C}$.

Biochemistry/immunoprecipitation. Cells and retinas were washed with PBS, minced in lysis buffer [containing (in mM): 50 Tris, $\mathrm{pH} 7.4,150$ $\mathrm{NaCl}, 1 \mathrm{EDTA}, 1 \mathrm{PMSF}, 1 \mathrm{Na}$-vanadate, $1 \mathrm{Na}$-fluoride, and $2.5 \mathrm{Na}$ pyrophosphate and protease inhibitor mixture plus $1 \%$ Triton X-100 (Calbiochem)] with 21 gauge needles and incubated on ice for $30 \mathrm{~min}$ with occasional shaking. Lysates were cleared by centrifugation ( $2 \mathrm{~min}$, $13000 \times g$ ), and protein concentrations were measured with the Bio-Rad protein assay (Hercules, CA). Immunoprecipitations with $5 \mu \mathrm{g} / \mathrm{ml}$ antibody or $5 \mu \mathrm{g} / \mathrm{ml}$ ephrinA5-Fc were incubated overnight at $4^{\circ} \mathrm{C}$. Subsequently, the antibodies were recovered with protein A-agarose (Roche, Palo Alto, CA) or protein G-Sepharose (Amersham Biosciences, Arlington Heights, IL), washed $3 \times 5 \mathrm{~min}$ with lysis buffer, and resuspended in sample buffer.

Immunoblotting. Proteins were separated by SDS-PAGE and transferred onto Hybond nitrocellulose membranes (Amersham Biosciences). Western blotting was done according to standard methods, using HRP-conjugated secondary antibodies (Bio-Rad) and the Western Lightning Chemiluminescence System (PerkinElmer Life Sciences, Emeryville, CA). Antibodies used were as follows: mouse anti-EphA4 (Transduction Laboratories, Lexington, KY); mouse anti-FLAG (Sigma); mouse anti-myc (9E10 clone), rabbit anti-pan-Src, rabbit anti-Fyn, and rabbit anti-Csk (1:1000; all from Santa Cruz Biotechnology); rabbit antiphospho-tyrosine (clone 4G10, Upstate Biotechnology, Lake Placid, $\mathrm{NY}$ ); and rabbit anti-ephexin (a kind gift of M. Greenberg, Boston, MA). For quantification we used the Phoretix 1D quantifier V4.0 program (Nonlinear Dynamics, Newcastle upon Tyne, UK).

Molecular biology. Constructs were amplified by PCR from E6 chicken total brain or mouse postnatal day 1 (P1) total brain cDNA generated with the micro fast track 2.0 kit and the cDNA Cycle kit (both from Invitrogen, San Diego, CA). Chicken Csk was cloned into the pca $\beta$ eGFP-m5 vector (a kind gift of Dr. J. Gilthorpe, King's College London, London, UK). Mouse ephexin and Fyn were cloned into pcDNA3.1MycHis vector (Invitrogen). A human Fyn expression construct was kindly provided by Dr. A. Magee (Imperial College London, London, UK). All constructs were verified by sequencing. Details of primers are available on request.
Stripe assay. Stripe assays were performed as previously described (Walter et al., 1987; Monschau et al., 1997). The HEK293 cell line expressing the long splice form of ephrinA5 was generated according to standard tissue culture techniques, and expression of this protein was tested routinely, using EphA-AP fusion proteins. Retinal explants were exposed to the reagents tested (PP2, PP3; Calbiochem) for the entire duration of the experiments.

For electroporation the chick retinal explants (either temporal or nasal thirds) were incubated with $40 \mu \mathrm{g}$ of Csk-green fluorescent protein (CskGFP) DNA (or GFP vector alone) for $20 \mathrm{~min}$. After that the retinas were electroporated by using five pulses with a silver wire (Goodfellow Cambridge, Huntingdon, UK; $0.5 \mathrm{~mm}$ diameter, $99.9 \%$ purity, temper annealing; CS204237JV) and the following settings on an Intracel electroporator (Intracept TSS10; Issaquah, WA): $50 \mathrm{~Hz}$ frequency, 1/manual mode, 50 msec delay, $50 \mathrm{msec}$ width, $50 \mathrm{~V}$. Explants were rinsed in HBSS, arranged onto nitrocellulose filters (Schleicher \& Schuell, Dassel, Germany), and cut into $275 \mu \mathrm{m}$ stripes. Retinal stripes were incubated with Neurobasal medium (Invitrogen) containing 2\% FCS for 2-3 d.

GFP-positive axons growing from the explant were counted on a Zeiss Axoscope (Oberkochen, Germany). Only GFP-positive axons with a minimum length of $\sim 100 \mu \mathrm{m}$ length were included in the quantification. Axons entering a posterior stripe $(\sim 50 \mu \mathrm{m}$ in width) were scored as being not repelled.

\section{Results}

\section{Src family kinases interact with EphA receptors in retinal neurons}

Multiple EphA receptors are expressed on chick retinal ganglion cell axons, e.g., EphA3, which is expressed almost exclusively on temporal axons, and EphA4, which is expressed more highly on nasal than on temporal axons (Cheng et al., 1995; Connor et al., 1998; Hornberger et al., 1999; Menzel et al., 2001; McLaughlin et al., 2003). The currently prevailing model is that the behavior of temporal axons in the stripe assay (Walter et al., 1987) depends on the expression (levels) of EphA receptors, whereas that of nasal axons depends on the expression (levels) of both EphAs and ephrinAs (Hornberger et al., 1999; Feldheim et al., 2000). Thus we have chosen the EphA4 receptor to investigate the role of EphA/SFKs in retinal axon guidance, more specifically to establish whether these EphA/SFK interactions occur in both nasal and temporal axons.

We initially used both an immunocytochemical (Fig. $1 A$ ) and a biochemical approach (Fig. $1 B, C$ ). In the first set of experiments the staining of explant cultures from nasal and temporal retina with anti-EphA4 and anti-pan-Src antibodies revealed a broad expression of both EphA4 and SFKs in the growth cone, with similar expression levels in both subpopulations of retinal axons (Fig. 1A). Superimposition of these staining patterns indicated a colocalization of EphA4 and SFKs in the retinal growth cone as well as in the axon shaft (Fig. 1A).

In our next approach we analyzed biochemically the interaction of EphA receptors and SFKs both in the fibroblast cell line HEK293 (Fig. 1 B,C) and in the chicken retina (Fig. 1D). HEK293 cells transfected with expression constructs encoding EphA3 ${ }^{\text {FLAG }}$ and Fyn ${ }^{\text {myc }}$ were immunoprecipitated by using either anti-FLAG or anti-myc antibodies (Fig. $1 B$ ). In line with previous reports from E. Pasquale's group (Ellis et al., 1996; Zisch et al., 1998), we found coimmunoprecipitation of EphA receptors and Fyn in both directions (Fig. $1 B$ ).

Next we investigated whether stimulation of EphA receptors with ephrinAs results in an increased recruitment of SFKs to EphA receptors as seen for EphB receptors (Vindis et al., 2003). In HEK293 cells transiently transfected with EphA3 FLAG, pan-Src immunoprecipitates from ephrinA5-Fc-treated cells contained more EphA receptors than immunoprecipitates from Fc-treated 
A
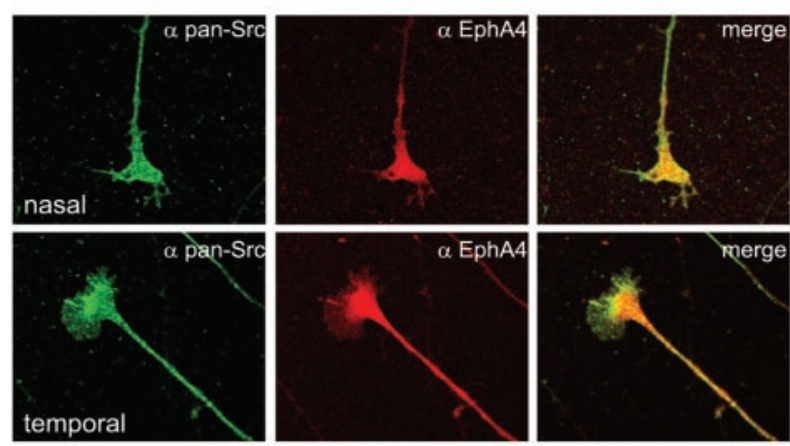

B
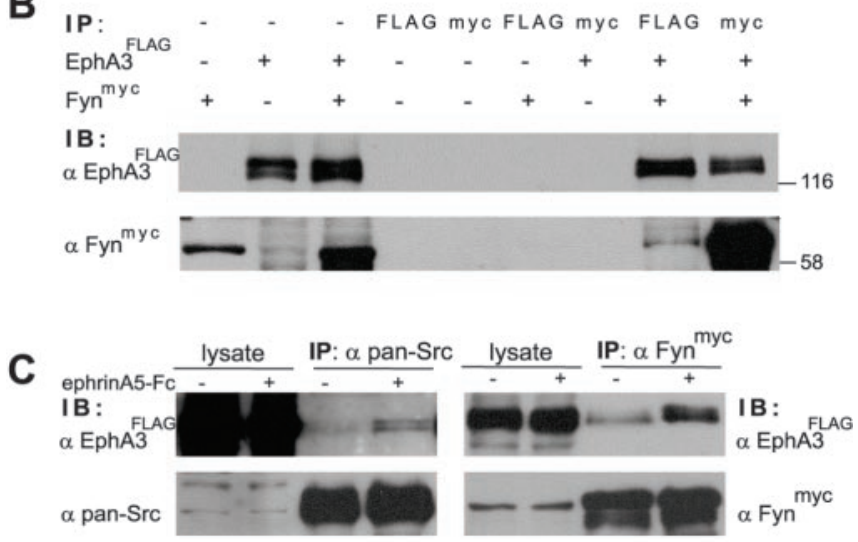

D

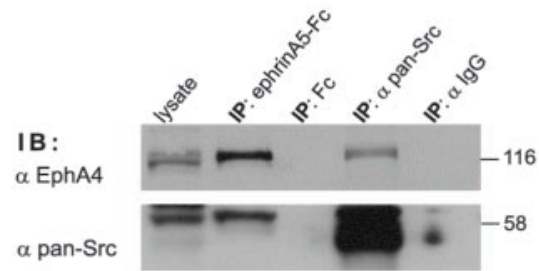

Figure 1. EphA receptors and SFKs interact in HEK293 cells and chicken retina. A, Nasal and temporal retinal explants were stained for expression of EphA4 receptors (red) and SFKs (green). Superimposition reveals a broad colocalization of EphAs and SFKs in the growth cone and axon shaft. B, HEK293 cells were transfected with EphA3 ${ }^{\text {FLAG }}$ and/or Fyn ${ }^{\text {myc }}$ or left untransfected. Lysates subsequently were immunoprecipitated with anti-FLAG or anti-myc antibodies and analyzed by immunoblotting. The results from both $\mathrm{EphA3}{ }^{\mathrm{FLAG}}$ and Fyn ${ }^{\mathrm{myc}}$ immunoprecipitates indicate an interaction of EphA receptors and SFKs in HEK293 cells. The specificity of this interaction is documented, for example, in myc and FLAG immunoprecipitates from cells transfected with EphA3 ${ }^{\mathrm{FLAG}}$ or Fyn ${ }^{\text {myc }}$ DNA only, where no such bands were detectable. $C$, Serum-starved HEK293 cells transfected with EphA3 ${ }^{\text {FLAG }}$ (left) or EphA3 ${ }^{\text {FLAG }}$ and Fyn ${ }^{\text {myc }}$ DNA (right) were stimulated for $15 \mathrm{~min}$ with $1 \mu \mathrm{g} / \mathrm{ml}$ preclustered $\mathrm{Fc}(-)$ or ephrinA5-Fc (+). EphA3 receptors were immunoprecipitated with endogenous SFKs (left) or Fyn ${ }^{\text {myc }}$ (right). Activation with ephrinA5 resulted in additional recruitment of both endogenous SFKs (left) and

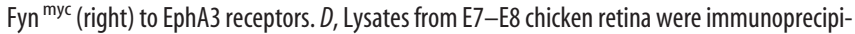
tated with ephrinA5-Fc (binding to multiple EphA receptors), Fc alone, anti-pan-Src antibodies, or control IgG antibodies. Samples were blotted with EphA4 antibodies (top) or a pan-Src antibody (bottom). Similar to results obtained in HEK293 cells (B, C), SFKs coprecipitate with EphA4 receptors in the chicken retina, and, vice versa, EphA4 also is found in SFK immunoprecipitates. Control immunoprecipitates that used Fc alone or lgG resulted in no EphA4 or SFK bands.

cells (Fig. 1C, left). The same induced recruitment of SFKs to EphA receptors was observed in HEK293 cells transfected with both EphA3 ${ }^{\text {FLAG }}$ and Fyn ${ }^{\text {myc }}$. Here again, stimulation with ephrinA5-Fc led to an increased interaction between EphA3 and Fyn (Fig. $1 C$, right) as compared with stimulation with $\mathrm{Fc}$ alone.

The interaction between SFKs and EphA receptors also was observed in chicken retina (Fig. 1D). Here SFKs were found in ephrinA5-Fc immunoprecipitates (binding to multiple EphA re-
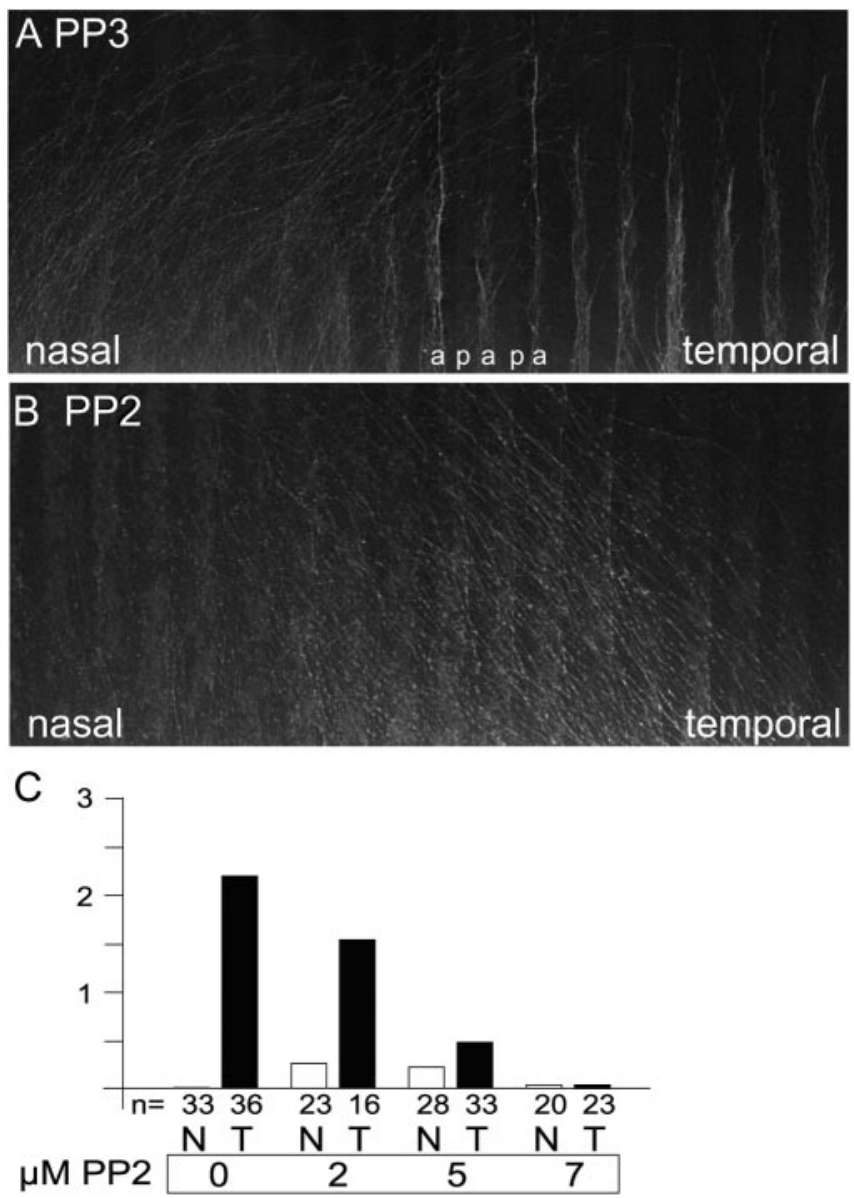

Figure 2. Repulsion of retinal axons by posterior tectal membranes in the stripe assay is abolished in the presence of the SFK inhibitor PP2. A, Retinal explants stained with 4-[4(didecylamino)styryl]- $N$-methypyridinium iodide (DiAsp) were arranged perpendicular to alternating lanes of membranes from anterior (a) and posterior ( $\mathrm{p}$; labeled with RITC-dextran) tectal thirds. After $2 \mathrm{~d}$ in culture the growth of retinal axons in the presence of the control compound PP3 was observed. Temporal retinal axons were repelled by posterior tectal membranes, thus giving a typically striped pattern of outgrowth. Nasal axons are not sensitive to posterior tectal membranes and grow out randomly. $B$, In the presence of $5 \mu \mathrm{MPP} 2$, the striped outgrowth of temporal axons is abolished completely. C, Quantification of the effects of various PP2 concentrations on retinal axons in stripe assay experiments, using alternating anterior versus posterior tectal membranes; $n$ refers to the number of retinal stripes analyzed. A score of 0 indicates random outgrowth of axons, whereas a score of 3 refers to maximal repulsion, with all retinal axons being repelled by posterior membranes.

ceptors) of retina from E7-E8 chick embryos, whereas immunoprecipitation with Fc alone did not yield any such bands. Moreover, EphA4 was also present in pan-Src immunoprecipitates from the entire retina, whereas an unrelated IgG did not precipitate any EphA4 receptors (Fig. 1D). In summary, our data show a ligand-induced association of EphA receptors and SFKs in retinal axons.

\section{Pharmacological inactivation of SFKs abolishes EphA- mediated repulsion of retinal axons}

To study SFKs in EphA function, we used well established in vitro assays, the stripe and growth cone collapse assays (Figs. 2-5). Because multiple, functionally redundant SFKs are expressed in retinal axons (see Introduction), we had to rely on strategies that would inactivate all members of this family simultaneously.

In the first set of experiments we used a pharmacological approach to block SFKs. Here we incubated retinal explants with the 
pyrazolopyrimidine PP2, a chemical compound widely used to inactivate SFKs (Hanke et al., 1996; Vindis et al., 2003). Because it was known that reducing SFK activity affects the ability of cells to migrate (Klinghoffer et al., 1999; Vindis et al., 2003), we first determined the PP2 concentrations that would allow us to study the guidance of retinal axons without severely diminishing neurite outgrowth itself. At $10 \mu \mathrm{M}$ PP2 the neurite outgrowth from retinal axons was, indeed, strongly decreased (data not shown); at $7.5 \mu \mathrm{M}$ we observed a reduced but sufficient outgrowth to perform stripe assay experiments, whereas at $5 \mu \mathrm{M}$ and lower concentrations the outgrowth was barely affected.

In these stripe assay experiments the explants from nasal and temporal parts of the retina were arranged on Nucleopore filters consisting of alternating lanes of membranes derived from anterior (a) and posterior (p) thirds of the optic tectum (Walter et al., 1987). Temporal axons expressing high concentrations of EphA receptors grow on membranes from their natural target in vivo, the anterior part of the tectum. This is attributable to repulsion from posterior tectal membranes, which contain higher concentrations of ephrinAs than anterior membranes. On the other hand, nasal axons are less sensitive to posterior tectal membranes, because of lower EphA concentrations and coexpression of ephrinAs (Hornberger et al., 1999; Feldheim et al., 2000; Knöll and Drescher, 2002), and grow out randomly (Fig. 2A). Inactivation of the EphA system by monomeric ephrinAs results in a complete abolition of the striped outgrowth pattern, indicating that the EphA system is necessary (and sufficient) for the in vitro guidance of retinal axons as seen in the stripe assay (Ciossek et al., 1998).

In the presence of $2 \mu \mathrm{M}$ PP2 the striped outgrowth of temporal axons was affected slightly; however, at 5 and $7 \mu \mathrm{M}$ PP2 they no longer were repelled from growing on posterior membranes, resulting in a random outgrowth (Fig. $2 B, C$ ). This means that inhibition of SFK results in the abolition of EphA-mediated repulsive axon guidance. Thus it appears that in particular at lower concentrations of PP2 the effects of this inhibitor on axon guidance versus axon outgrowth can be distinguished.

Additionally, at concentrations of 2 and $5 \mu \mathrm{M}$ PP2 we observed a subtle but reproducible striped outgrowth of nasal axons on anterior lanes in contrast to the random outgrowth of nasal axons in controls (Figs. 2C, $4 B$ ). This effect was seen no longer at $7 \mu \mathrm{M}$ PP2. Control stripe assay experiments were performed with the chemically similar but functionally inactive compound PP3, which did not affect the outgrowth or strength of the guidance decision (Fig. 2A).

Next we performed experiments to demonstrate directly that the observed abolition of striped outgrowth (Fig. 2) was attributable to blocking EphA-ephrinA-mediated guidance (Fig. 3). For this we performed a series of stripe assay experiments that used alternating lanes of membranes from a HEK293 cell line stably expressing ephrinA5 and the parental HEK293 cell line. In contrast to stripe assay experiments that used tectal membranes (Fig. $2 A)$, here both temporal and nasal axons were repelled from ephrinA5-containing membranes (Fig. 3A). In controls (HEK293 vs HEK293 membranes) no patterned outgrowth is observed (data not shown). The repulsion of nasal axons is believed to be attributable to the higher concentrations of ephrinA5 on transfected HEK293 cell membranes than on tectal membranes (Monschau et al., 1997). As expected, blocking SFK function with $5 \mu \mathrm{M}$ PP2 resulted in a random, nonstriped outgrowth of both nasal and temporal retinal axons (Fig. $3 B, C$ ). These results strongly suggest that EphA-mediated repulsive axon guidance that uses either tectal membranes (Ciossek et al., 1998) or
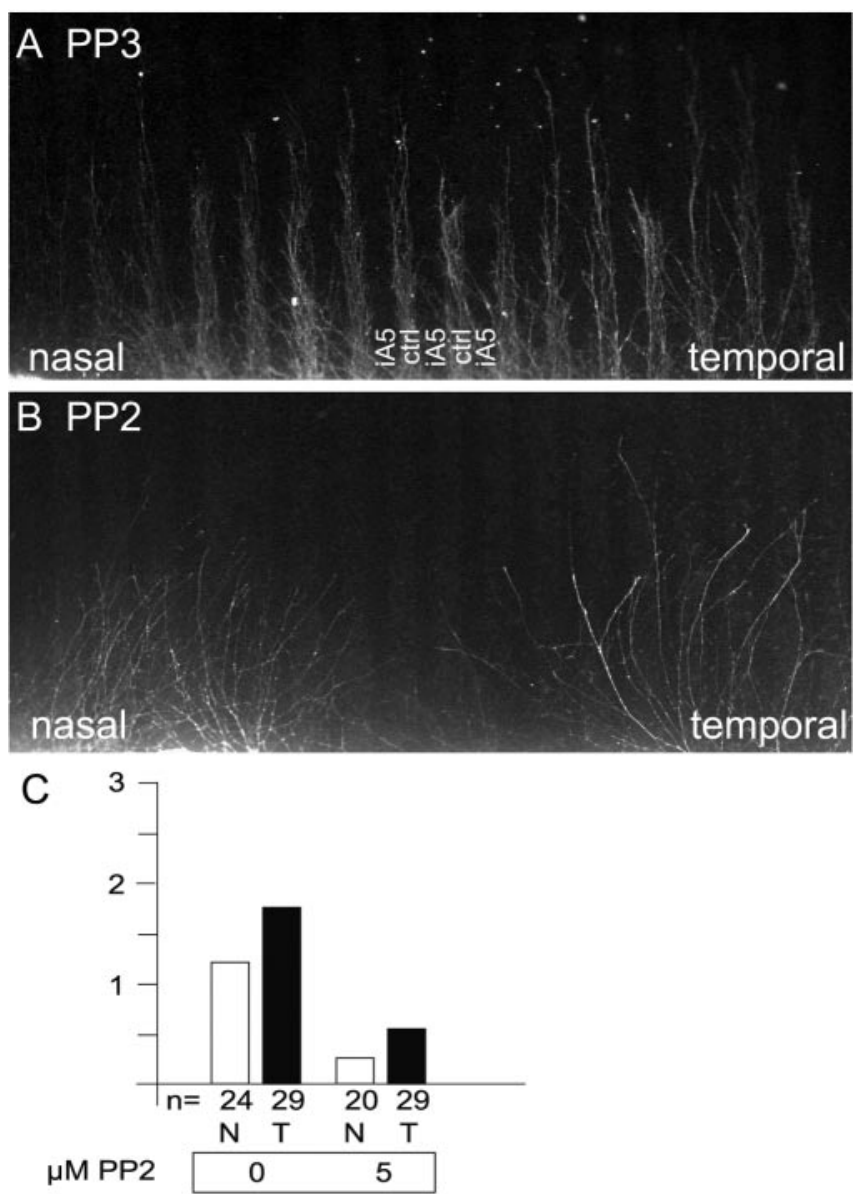

Figure 3. Inhibiting SFK activity with PP2 abolishes EphA-mediated repulsion. Retinal axons were given the choice to grow on alternating lanes consisting of membranes derived from an ephrinA5-expressing cell line (iA5; labeled with RITC-dextran) versus the corresponding parental cell line (ctrl). As a growth-promoting substrate, laminin was added. $A$, Both nasal and temporal retinal axons show a striped outgrowth because of EphA-mediated repulsion. $B$, In the presence of $5 \mu \mathrm{MPP} 2$, both nasal and temporal axons grow out in a random manner, insensitive to the repulsive effects of ephrinA5. C, Quantification of these stripe assays experiments (see Fig. 2 for details). After incubation with $5 \mu \mathrm{MPP}$, the ephrinA5-mediated repulsion of retinal axons is strongly reduced.

ephrinA5-HEK293 membranes can be abolished by inhibiting SFK-mediated tyrosine phosphorylation.

\section{Inhibiting SFKs by overexpression of Csk reduces EphA-mediated repulsion}

In addition to blocking SFK function pharmacologically (Figs. 2, $3,5)$, we complemented these studies with a cell biological approach (Fig. 4). For this we overexpressed a negative regulator of SFK function, Csk, in retinal axons, a process that we anticipated would decrease the activity of all SFKs present in these axons (see Introduction).

We generated a Csk-GFP fusion protein to monitor electroporated axons in subsequent analyses. The expression in retinal axons and HEK293 cells of a Csk-GFP fusion protein with the correct molecular weight was verified by Western blotting (Fig. $4 A$ ). Two experiments suggested that overexpression of Csk in retinal axons results in a reduction of SFK activity: first, tyrosine phosphorylation of SFKs was enhanced after Csk overexpression; second, the use of an antibody binding only to activated SFKs (Kawakatsu et al., 1996) showed a weaker staining for SFKs by using membranes of Csk-GFP-transfected HEK293 cells as com- 
A

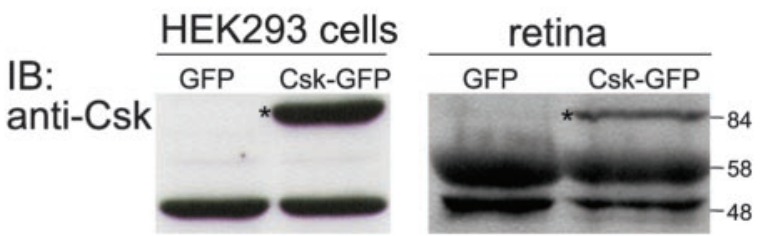

B

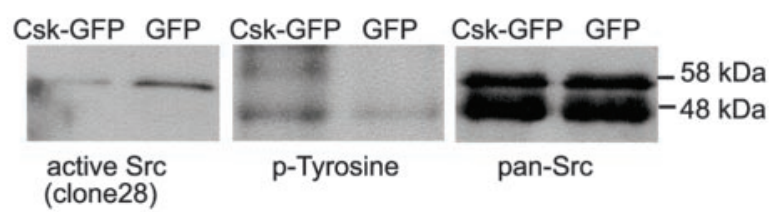

C
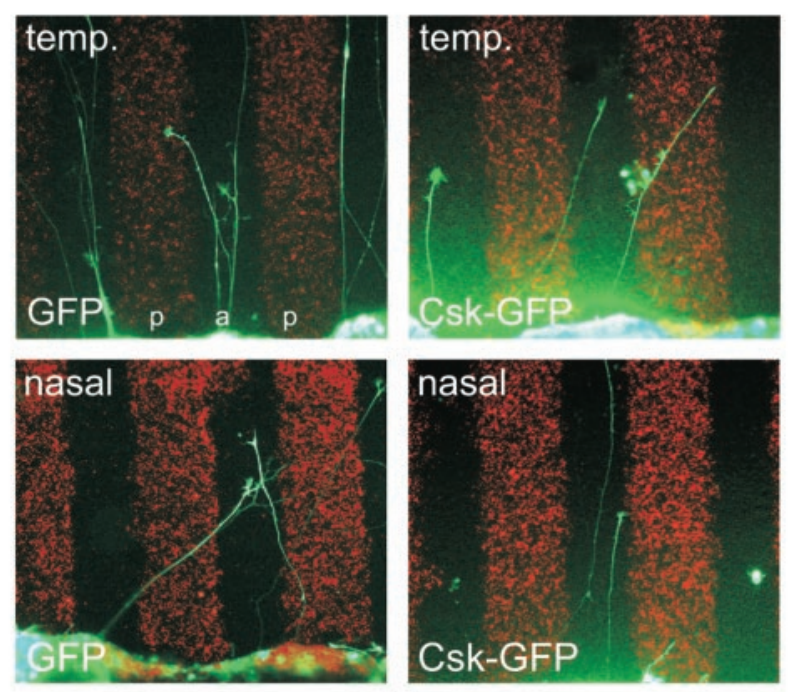

D

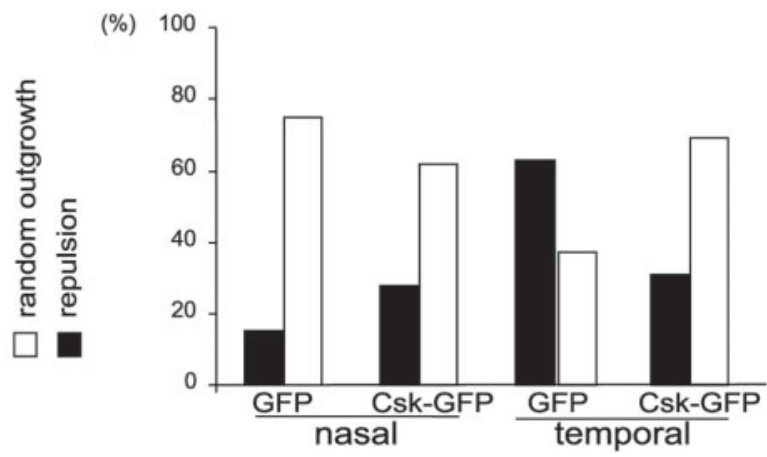

Figure 4. Overexpression of the SFK inhibitor (sk interferes with the guidance of retinal axons in vitro. A, Csk-GFP or GFP alone was expressed in HEK293 cells (left) or single cells from E7 retina (right). Cell lysates were analyzed by immunoblotting with an anti-Csk antibody verifying expression of the (sk-GFP fusion protein in these cells (indicated by an asterisk). B, Lysates of HEK293 cells transfected with Csk-GFP or GFP alone were subjected to immunoprecipitation with a pan-Src antibody. An antibody recognizing the active form of SFKs (clone 28) revealed a decrease in SFK activity after (sk-GFP overexpression as compared with GFP alone (left). The overall tyrosine phosphorylation (middle) of SFKs is elevated in Csk-GFP-transfected HEK293 cells, indicating SFK phosphorylation by Csk. Equal loading of SFKs is documented by probing with the pan-Src antibody (right). C, In stripe assay experiments, the temporal or nasal retina was electroporated with GFP or Csk-GFP expression constructs. Subsequently, the retinas were cut into stripes and arranged on filters containing alternating lanes of anterior (a) versus posterior (p) tectal membranes. Membrane stripes were labeled by the addition of RITC-dextran. After $2 \mathrm{~d}$ in culture, the guidance behavior of GFP-positive axons was evaluated. Here, typical examples are shown. Overexpression of Csk reduces the number of temporal axons being repelled by posterior membranes. In contrast, expression of Csk-GFP in nasal axons led to an increase in the number of nasal axons being repelled by posterior membranes. D, Quantification of the effects of overexpressing Csk-GFP/GFP on retinal axon guidance in vitro. For each condition, pared with SFKs from control HEK293 membranes (Fig. 4B) (Howell and Cooper, 1994; Nakagawa et al., 2000).

We developed an electroporation technique to deliver the Csk-GFP expression construct (or GFP as a control) into retinal explants (Fig. 4C). This enabled us to express Csk-GFP (or GFP alone) in $\sim 2-5 \%$ of retinal axons emanating from these explants. However, we routinely observed a lower number of Csk-GFPpositive than GFP-positive axons. Thus expression of Csk-GFP led to a $30-40 \%$ decrease in the number of labeled axons as compared with cultures electroporated with GFP alone (data not shown). This most likely is caused by an interference of Csk with SFK function in retinal ganglion cells and thus is comparable to results from experiments in which high concentrations of PP2 were used (see above).

We then analyzed the guidance behavior of Csk-overexpressing axons in stripe assays, using alternating anterior versus posterior tectal membranes (compare Figs. 2, 4C). Because of the smaller number of axons evaluated in these stripe assays, the quantification method was modified as described in Materials and Methods. Here we observed an $\sim 50 \%$ drop in the number of temporal axons being repelled by posterior tectal membranes (from 63 to $31 \%$ ) (Fig. 4C,D). Thus because the preference of temporal axons to grow on anterior membranes is attributable to repulsive guidance by the EphA system (Ciossek et al., 1998), these data indicate that overexpression of Csk in temporal axons interferes with EphA receptor-mediated axon guidance. In axons expressing only GFP, the majority of temporal axons (63\%) still was repelled robustly, suggesting that overexpression of GFP or the electroporation itself had little effect on the guidance of temporal axons.

As expected, the number of nasal axons sensitive to ephrinAs was small (15\%; with or without expressing GFP); thus most of the axons grew out randomly (Fig. 4C,D). Strikingly, however, almost twice as many nasal axons $(28 \%)$ were repelled by posterior membranes after overexpression of Csk-GFP. This correlated well with the previous observation that incubation with PP2 increased (slightly) the sensitivity of nasal axons toward posterior tectal membranes (Fig. 2). The functional significance of these results is currently under investigation; however, it is known that reverse signaling of ephrinAs, which are expressed on nasal axons, does involve SFKs (see Discussion) (Davy et al., 1999; Huai and Drescher, 2001).

\section{SFKs are required for ephrinA-mediated growth cone collapse}

To characterize the effect of SFK inhibition on retinal axon guidance in a second assay system, we used the growth cone collapse assay (Cox et al., 1990; Raper and Kapfhammer, 1990). Nasal and temporal retinal axons were pretreated with $5 \mu \mathrm{M}$ PP2 for $30 \mathrm{~min}$ before different amounts of ephrinA5-Fc or ephrinA5-AP were applied to induce retinal growth cone collapse (Fig. $5 A, B$ ), which was monitored by time-lapse microscopy (Fig. $5 A$ ). We found that pretreatment with PP2 strongly reduced the percentage of ephrinA5-induced growth cone collapse (Fig. 5B). In controls, 100\% of temporal retinal growth cones collapsed after incubation with 0.1

the outgrowth behavior of 300 - 400 GFP or Csk-GFP-positive axons was scored ( 3 independent experiments). The majority of temporal axons electroporated with GFP alone was repelled by posterior membranes (63\%), whereas expression of (sk-GFP led to an $\sim 50 \%$ reduction in repulsion (31\%). Nasal axons expressing GFP alone were repelled rarely by posterior membranes (15\%), whereas an almost twofold increase in the number of (sk-GFP-positive nasal axons being repelled (28\%) was noticed. 


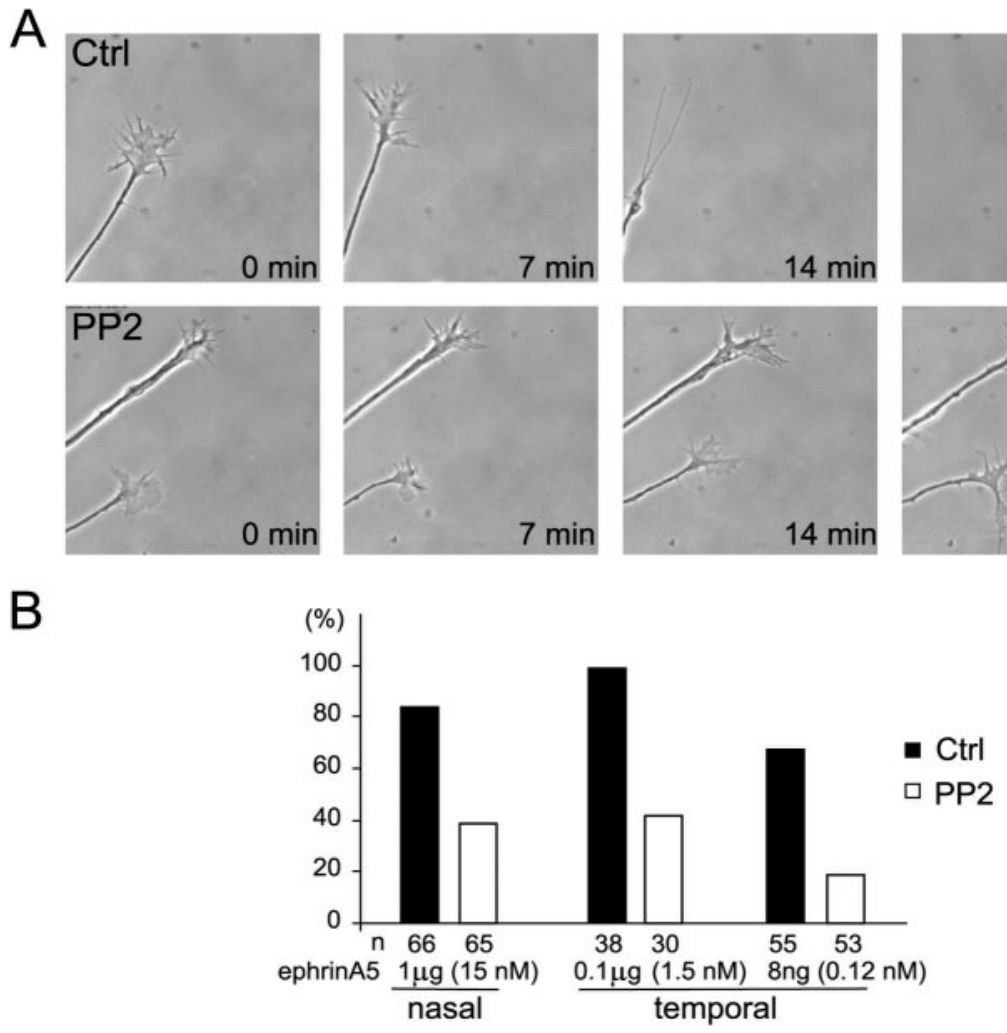

Figure 5. SFKs are involved in mediating ephrinA5-induced growth cone collapse. $A$, Nasal or temporal retinal explants were preincubated for $30 \mathrm{~min}$ with $5 \mu \mathrm{MPP} 2$ before ephrinA5 was applied $(0 \mathrm{~min})$. The behavior of growth cones was monitored every 3-4 min, using time lapse starting $10 \mathrm{~min}$ before and lasting at least $30 \mathrm{~min}$ after the addition of ephrinA5 to the cultures. Top, In the presence of PP3 (control, Ctrl); bottom, in the presence of PP2. B, The bars indicate the percentage of growth cone collapse of either nasal or temporal axons; $n$ refers to the number of growth cones analyzed. In summary, after incubation with PP2, the nasal and temporal growth cones were less sensitive toward the repulsive activity of ephrinA5.

$\mu \mathrm{g}$ of ephrinA5, whereas in $5 \mu \mathrm{M}$ PP2 only $43 \%$ of temporal axons collapsed.

In summary, these data are in good agreement with results obtained from the stripe assay experiments (Figs. 2-4) and strengthen the idea of an important role of SFKs in EphA receptor-dependent axon repulsion.

\section{SFKs tyrosine-phosphorylate EphA receptors}

The abolition of retinal axon guidance after treatment with PP2 (Figs. 2, 3) could be explained in at least two ways. First, PP2 might inactivate the EphA kinase (which normally mediates auto-tyrosine phosphorylation after ligand binding). Second, after binding to EphAs in the retina, SFKs might tyrosinephosphorylate EphA receptors, an activity that would be abolished after PP2 treatment.

To discriminate between these possibilities, we made use of the SYF fibroblast cell line derived from E9.5 $\mathrm{src}^{-1-}, \mathrm{fyn}^{-1-}$, $\mathrm{yes}^{-1-}$ triple mouse mutants, which does not show any detectable SFK activity (Klinghoffer et al., 1999). Use of this cell line allowed us to analyze the tyrosine phosphorylation state of EphA receptors without interference from endogenously expressed SFKs. SYF cells transfected with EphA3 ${ }^{\text {FLAG }}$ were preincubated with PP2 (or PP3 as a control), followed by stimulation with either ephrinA5-Fc or Fc (Fig. 6A). EphrinA5-Fc induced a strong increase in the phosphorylation of EphA3, which was not affected by $2 \mu \mathrm{M}$ PP2 and was decreased only marginally $(\sim 15 \%)$ by $5-7$ $\mu$ M PP2 (Fig. 6A, 3 independent experiments). Similar data re- cently were reported for other cell lines (Takasu et al., 2002; Vindis et al., 2003). Thus PP2 does not interfere with the EphA kinase.

Next we analyzed whether SFK expression increases the tyrosine phosphorylation of EphA receptors (Fig. 6B). In these experiments EphA3 ${ }^{\mathrm{FLAG}}$ with or without a Fyn expression construct was transfected into serum-starved SYF cells and stimulated with ephrinA5-Fc. Compared with the tyrosine phosphorylation of EphA3 alone, coexpression with Fyn robustly increased EphA3 phosphorylation (1.8-fold; $n=4$ experiments). This increase occurred on top of that of EphA tyrosine phosphorylation caused by stimulation with ephrinA5. Significantly, incubation of SYF cells with PP2 resulted in a decrease in EphA3 phosphorylation (Fig. 6B) to basal levels.

Taken together, our data show that the SFK inhibitor PP2 only marginally affects the autophosphorylation of EphA receptors, whereas SFKs themselves are able profoundly to increase the tyrosine phosphorylation of EphA receptors. SFKs thus might contribute in this way to the regulation of EphA receptor signaling.

\section{What are the targets of SFK tyrosine phosphorylation in the chicken retina?}

We were interested in identifying retinally expressed proteins interacting with EphA receptors, which are tyrosine-phosphorylated by SFKs. For this purpose, EphA receptors were immunoprecipitated from chicken retina by using either ephrinA5-Fc or anti-EphA4 antibodies. Both reagents gave similar results, and here only data that use ephrinA5-Fc are shown ( $n=8$ experiments) (Fig. 7). To detect proteins tyrosinephosphorylated by SFKs, we pretreated retinal tissue with $5 \mu \mathrm{M}$ PP2, $2.5 \mu \mathrm{M}$ SU6656 [another SFK inhibitor (Blake et al., 2000)], or $5 \mu \mathrm{M}$ PP3 (as control). Also, to unravel (possible) differences between nasal and temporal axons, we investigated corresponding retinal thirds separately.

A number of tyrosine-phosphorylated proteins coimmunoprecipitated specifically with the EphA receptor, in particular proteins with molecular weights of $\sim 120,80$, and $55 \mathrm{kDa}$ (Fig. 7). In controls that use $\mathrm{Fc}$ for immunoprecipitation, none of these bands was detected (Fig. 7, right). p55 and p120 were identified as SFKs and EphA receptors, respectively (Fig. 7). With PP2 and SU6656 incubation the phosphotyrosine level of the $80 \mathrm{kDa}$ proteins was decreased most strongly (Figs. 7, 8). Closer inspection of these proteins showed them to separate into a triple band, with an upper doublet being more strongly tyrosine-phosphorylated than the smaller third band, which was phosphorylated rather weakly (Figs. 7, 8C).

\section{Ephexin and cortactin as potential targets of SFK tyrosine phosphorylation}

The RhoGEF ephexin, which plays an important role in retinal growth cone collapse, is associated constitutively with EphA receptors and has a molecular weight of $70-80 \mathrm{kDa}$ (Shamah et al., 2001). It thus represents a good candidate for one of the tyrosine- 

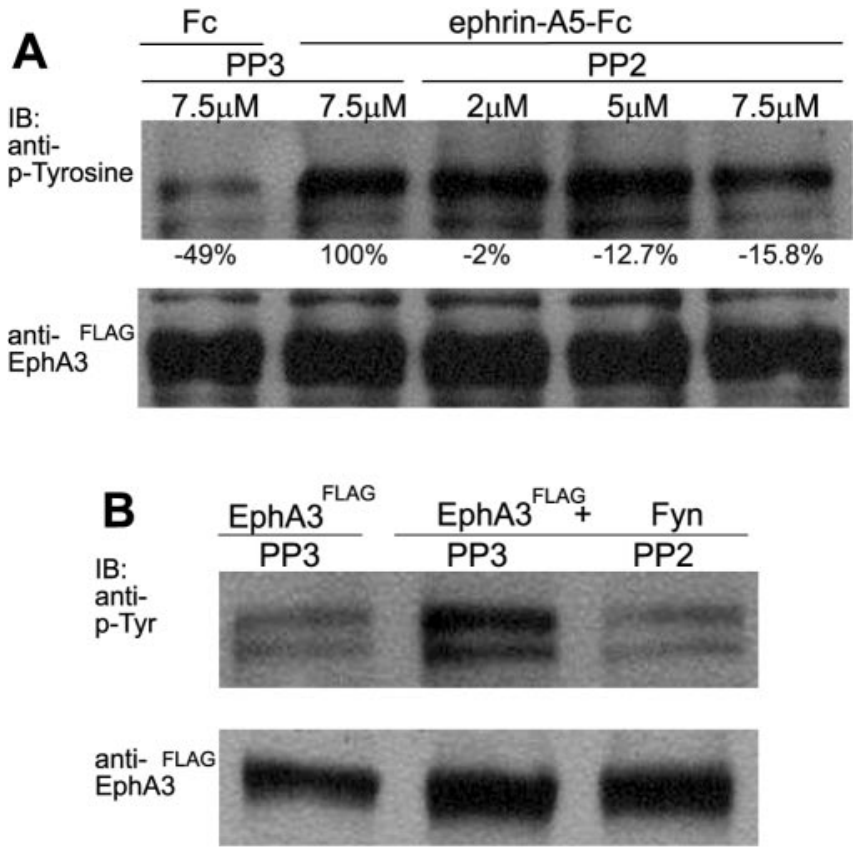

Figure 6. Fyn overexpression increases tyrosine phosphorylation of EphA receptors. $A$, EphA3 ${ }^{\mathrm{FLAG}}$ expressing SYF cells $\left(\mathrm{src}^{-1-}\right.$, fyn $^{-1-}{ }^{-}$, yes ${ }^{-1-}$ ) were stimulated with ephrinA5-Fc in the presence of increasing concentrations of PP2. Compared with $\mathrm{Fc}$ alone, ephrinA5-Fc induced a robust tyrosine phosphorylation on EphA3 ${ }^{\text {FLAG }}$. The phosphorylation of EphA3 was not affected by $2 \mu \mathrm{MPP} 2$ and only modestly at $5-7.5 \mu \mathrm{MPP} 2$. The percentages given indicate relative changes in EphA phosphorylation, taking the value at $7.5 \mu \mathrm{m}$ PP3 as 100\%. This indicates that the SFK inhibitor PP2 has only a marginal effect on the auto-tyrosine phosphorylation of EphA receptors. B, SYF cells transfected with EphA ${ }^{\mathrm{FLAG}}$ alone or together with Fyn were serum-starved and stimulated with ephrinA5-Fc. Lysates were analyzed by anti-FLAG and antiphospho-tyrosine antibodies. Compared with controls, the tyrosine phosphorylation of EphA3 strongly increased (1.8-fold; $n=4$ experiments) when Fyn was coexpressed in SYF cells. This increase was blocked by preincubation of the cells with PP2. Similar data were obtained for the analysis of EphA receptor immunoprecipitates.

phosphorylated $80 \mathrm{kDa}$ proteins found in EphA immunoprecipitates. To verify this possibility, we initially coexpressed EphA3 ${ }^{\text {FLAG }}$ and a myc-tagged version of ephexin (ephexin ${ }^{\text {myc }}$ ) in HEK293 cells. Coimmunoprecipitation experiments showed an interaction between these proteins (Fig. $8 \mathrm{~A}$ ). In addition, we observed a robust tyrosine phosphorylation of ephexin, which was reduced significantly with $\mathrm{PP} 2$ treatment, indicating that ephexin can be phosphorylated by SFKs (Fig. $8 B$ ).

When phosphotyrosine and ephexin Western blots are compared, ephexin co-migrated with the smallest of the three $80 \mathrm{kDa}$ proteins (see above), showing comparatively little tyrosine phosphorylation in the retina (Figs. 7, 8C). Indeed, it appears that the tyrosine phosphorylation level of ephexin in the retina is quite low, as judged from direct ephexin immunoprecipitation from the chicken retina, followed by Western blot analysis (data not shown).

A second candidate molecule for the $80 \mathrm{kDa}$ proteins was cortactin, characteristically migrating in protein gels as a doublet of $\sim 80$ and $85 \mathrm{kDa}$ (Weed and Parsons, 2001). Cortactin is a well known target of SFK tyrosine phosphorylation and binds to EphA receptors in muscle cells (Lai et al., 2001). Coimmunoprecipitations in both directions that use ephrinA5-Fc (Fig. 8D, middle) or anti-cortactin antibodies (Fig. $8 D$, left) confirmed the interaction between cortactin and EphA4 receptors in retinal tissue. In addition, we identified cortactin as a doublet in our protein gels that precisely co-migrated with the two upper $80 \mathrm{kDa}$ phosphoproteins. Thus it appears that the $80 \mathrm{kDa}$ proteins coprecipitating

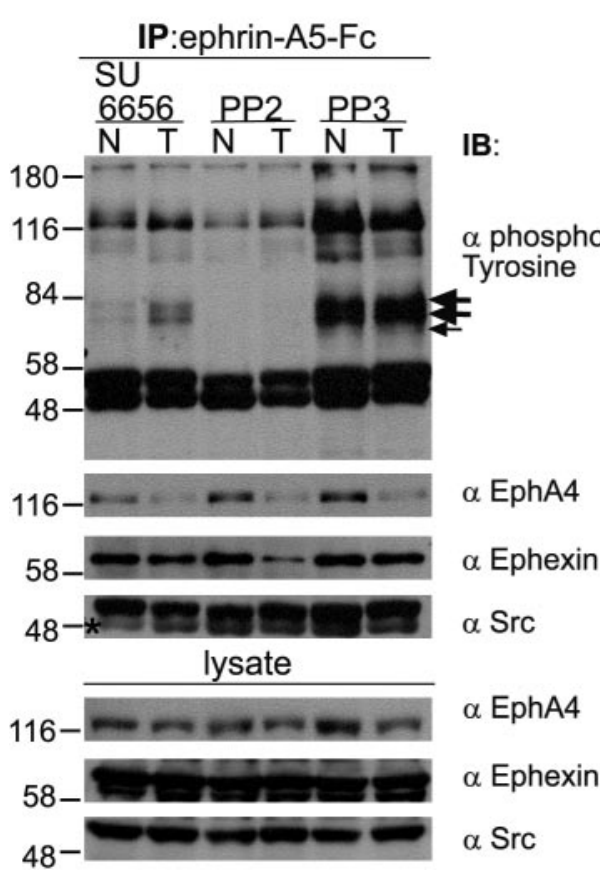

Figure 7. SFKs control the tyrosine phosphorylation of multiple proteins interacting with EphA receptors in the chicken retina. Left, Nasal or temporal retinal thirds from E7-E8 chicken embryos were incubated with the SFK inhibitors SU6656 (2.5 $\mu \mathrm{M})$ or PP2 $(5 \mu \mathrm{M})$ or the control compound PP3 (5 $\mu \mathrm{m})$. Subsequently, EphA receptors were immunoprecipitated with ephrinA5-Fc and probed with anti-phospho-tyrosine antibodies. These experiments uncovered a number of tyrosine-phosphorylated proteins coprecipitating with EphA receptors, including proteins with molecular weights of $\sim 55,80$, and $120 \mathrm{kDa}$, which were identified consistently in both nasal and temporal retina. p55 and p120 correspond to SFKs and EphA receptors, respectively, as revealed by the probing of duplicate samples with pan-Src and EphA4 antibodies. Shorter exposure of blots also uncovered a reduction in the tyrosine phosphorylation of SFKs, which is in agreement with reports showing that autophosphorylation of SFKs is affected after PP2 treatment (Frame et al., 2002). Also, the RhoGEF ephexin could be detected in EphA immunoprecipitates (see Fig. 8). A reduction in the tyrosine phosphorylation after incubation with SFK inhibitors PP2 or SU6656 is evident for some proteins, in particular the $80 \mathrm{kDa}$ proteins (indicated by 3 arrows). The tyrosine phosphorylation of EphA receptors also is reduced after SFK inhibition (see Fig. 6). The asterisk in the $\alpha$-Src panel indicates the position of ephrinA5-Fc. Right, Immunoprecipitates prepared with Fc alone were analyzed by the use of phosphotyrosine antibodies and resulted in no signal.

with EphA receptors represent the actin-binding protein cortactin and the RhoGEF ephexin.

\section{Discussion}

The repulsive response mediated by EphA receptors on navigating axons is important throughout neural development to ensure the precise targeting of axons. Elucidation of the signaling cascades activated by Eph receptors that cause changes in cytoskeletal dynamics is an important step toward a better understanding of the mechanisms of axon guidance.

Multiple signaling pathways are modulated after EphA receptor activation (Kullander and Klein, 2002), such as MAP kinase and integrin signaling, and ephexin signaling to the small GTPases RhoA, Rac, and Cdc42, the key regulatory molecules in actin cytoskeleton dynamics (Hall and Nobes, 2000).

\section{SFKs are essential for retinal axon guidance}

Here we have added SFKs to the list of essential downstream signaling molecules of EphA receptors in retinal axon guidance. The inhibition of SFKs, either pharmacologically or enzymatically via overexpression of the SFK inhibitor Csk, led to an abo- 

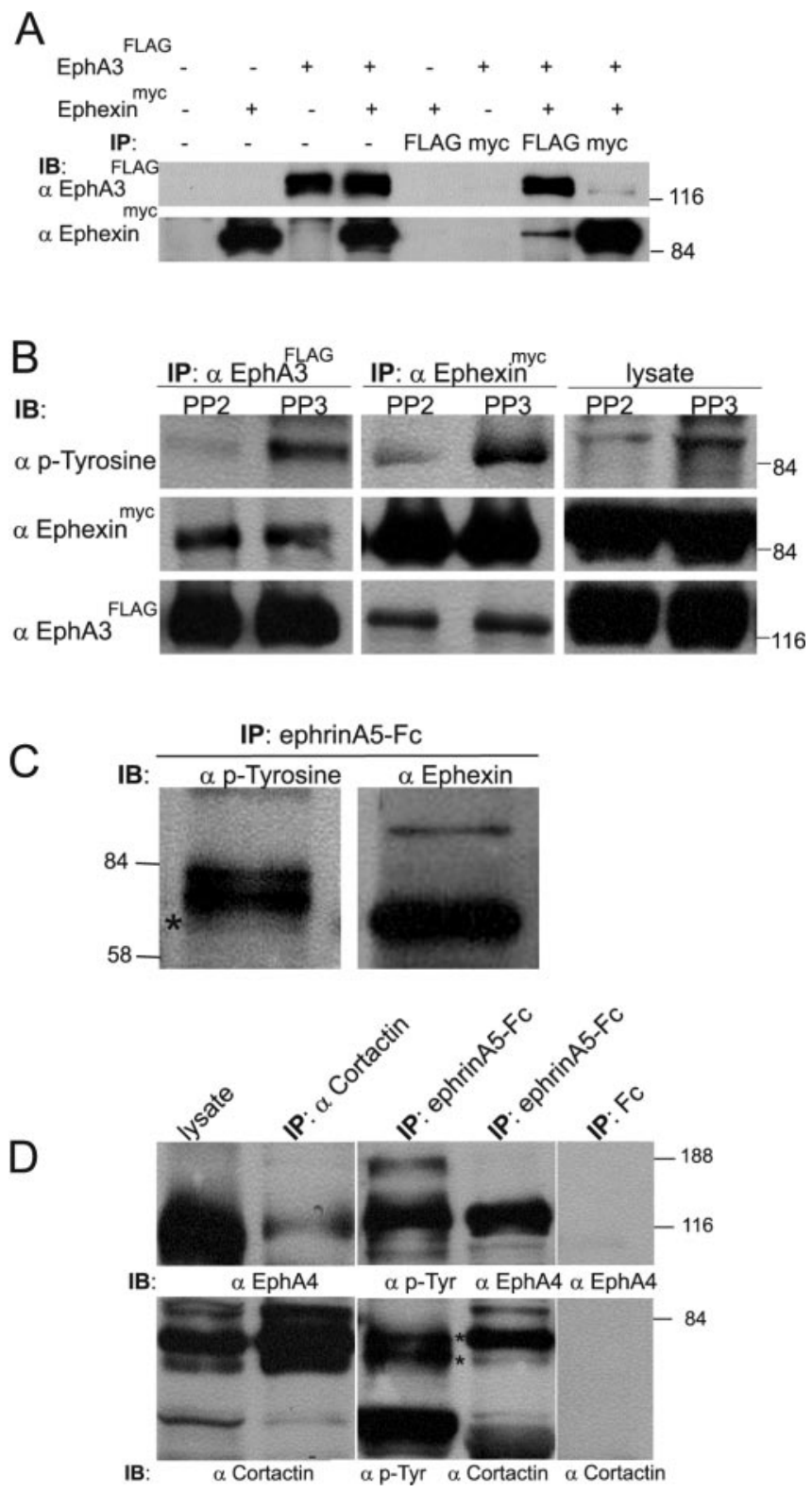

Figure 8. Ephexin and cortactin coimmunoprecipitate with EphA receptors. HEK293 cells were analyzed in $A, B$, and retinal tissue in C, D. A, HEK293 cells were transfected with EphA3 ${ }^{\text {FLAG }}$ and/or ephexin ${ }^{\text {myc }}$, and lysates were immunoprecipitated by using FLAG or myc antibodies. Results from both Flag and myc immunoprecipitations demonstrate interaction of ephexin ${ }^{\text {myc }}$ and EphA3 ${ }^{\text {FLAG }}$. FLAG or myc antibodies did not bind nonspecifically to lysates from HEK293 cells transfected with either ephexin ${ }^{\text {myc }}$ or EphA3 ${ }^{\text {FLAG }}$ only. B, HEK293 cells cotransfected with EphA3 ${ }^{\text {FLAG }}$ and ephexin ${ }^{\text {myc }}$ were serum-starved, preincubated with PP2 or PP3, and stimulated with ephrinA5-Fc (see Materials and Methods). Lysates and FLAG or myc immunoprecipitates were immunoblotted for ephexin ${ }^{\text {myc }}$, EphA3 ${ }^{\text {FLAG }}$, and phospho-tyrosine. These data indicate a specific interaction of EphA receptors with ephexin. Preincubation with PP2 led to a decrease in the tyrosine phosphorylation level of ephexin ${ }^{\text {myc }}$, suggesting that SFKs phosphorylate ephexin in HEK293 cells. C, Parallel analysis of EphA receptor immunoprecipitates with anti-ephexin and anti-phospho-tyrosine antibodies. Ephexin co-migrates with the smallest of the tyrosinephosphorylated $80 \mathrm{kDa}$ proteins (indicated by asterisk; also see Fig. 7). D, Left, EphA receptors coimmunoprecipitate with cortactin. The rather weak amount of EphA receptor coprecipitating might be attributable to the facts that, first, cortactin is expressed in all cells of the retina, whereas EphA receptors are confined to the ganglion cell layer, and, second, only a fraction of cortactin might be associated with EphA receptors in these cells. Middle, Cortactin coimmunoprecipitates with EphA receptors. The EphA immunoprecipitate (prepared with ephrinA5-Fc) contains cortactin, which migrates as a doublet of bands at $\sim 80 \mathrm{kDa}$ (indicated by two asterisks), with a typically stronger upper band. These two bands migrate at exactly the same height as the top two tyrosine-phosphorylated $80 \mathrm{kDa}$ proteins previously identified (see Fig. 7). Right, Neither EphA4 nor cortactin is found in Fc immunoprecipitates. lition of EphA-mediated repulsion in the stripe assay and the growth cone collapse assay (Figs. 2-5). Very recently, similar data that used pharmacological inactivation of SFKs in the growth cone collapse assay also were obtained by Wong et al. (2004). SFKs colocalize with EphA receptors in retinal growth cones (Fig. 1) (Zisch et al., 1998) and are recruited to EphA receptors after stimulation by ephrin ligands (Fig. 1) (Takasu et al., 2002; Vindis et al., 2003). SFK activation, which peaks after $\sim 5 \mathrm{~min}$ (Vindis et al., 2003), might be one of the very early steps in the events leading to Eph receptor-triggered (local) breakdown of the growth cone cytoskeleton. At present it is not known which particular SFKs are involved in retinal axon guidance. It has been shown that all three SFKs expressed in retinal neurons (Src, Yes, Fyn) bind to various EphAs in retinal tissue (Zisch et al., 1998), with the SFK-binding motif highly conserved among different members of the EphA family. In these studies Src itself was identified as the SFK with the highest affinity for EphA receptors (Zisch et al., 1998). On the other hand, Fyn was identified as the SFK member primarily associated with cortactin regulation (see below) (Kapus et al., 2000; Huang et al., 2003; Fan et al., 2004). Thus it will be important in additional experiments to investigate which SFK member contributes to EphA-mediated retinal axon guidance.

\section{Targets of Src family kinases in retinal axons}

There are multiple potential targets of SFKs, and an understanding of SFK function in retinal axon guidance might be achieved by identifying targets of SFK tyrosine phosphorylation in retinal growth cones. In this report we characterized a number of proteins in EphA immunoprecipitates for which the tyrosine phosphorylation was regulated by SFKs, in particular proteins of $\sim 120,80$, and $55 \mathrm{kDa}$. Because the 120 and $55 \mathrm{kDa}$ bands were found to be EphA receptors and SFKs, respectively, we focused our attention on the identification of the proteins at $\sim 80 \mathrm{kDa}$. Closer inspection revealed two proteins that were strongly tyrosine-phosphorylated, whereas the third and smallest protein was phosphorylated rather weakly (Fig. 7).

\section{Cortactin}

A doublet of tyrosine-phosphorylated bands at $\sim 80 \mathrm{kDa}$ is a pattern well documented for the actin-binding protein cortactin (for review, see Weed and Parsons, 2001). Our tyrosine phosphorylation and EphA coimmunoprecipitation experiments strongly suggest that this doublet at $80 \mathrm{kDa}$ is indeed cortactin (Fig. $8 D$ ). Additionally, it is known that the activity of cortactin is downregulated via SFK-mediated tyrosine phosphorylation (Huang et al., 1997a,b), that it is localized to growth cones (Du et al., 1998), and that it can interact with EphA receptors (in muscle cells) (Lai et al., 2001). With stimulation the cortactin is recruited to the membrane, where it activates the Arp2/3 complex (Weed et al., 1998; Weaver et al., 2001) that plays a central role in de novo actin polymerization, i.e., its stability and branching. The Arp2/3 complex also is activated by WASP family members (Weed and Parsons, 2001), which in turn are controlled by the small GTPases $\mathrm{Cdc} 42$ and Rac (see below).

Thus the SFK/cortactin-controlled signaling pathway might contribute to repulsive growth cone turning via local activation of EphA receptors and SFKs, leading to inactivation of cortactin and a decrease in the activity of the Arp2/3 complex (Huang et al., 1997a,b). In addition, the inactivation of cortactin also releases the block on debranching of Arp2/3 networks and so might trigger a cofilin-mediated breakdown of the actin cytoskeleton (Weed and Parsons, 2001). Also, a recent study by Fan et al. (2004) suggests that tyrosine phosphorylation of cortactin may 
occur as a result of actin depolymerization and thus may be a secondary event to EphA-mediated (partial) growth cone collapse. Future experiments will need to investigate the correlation between EphA receptor-mediated growth cone collapse and the phosphorylation state of cortactin in retinal axons, using phospho-specific antibodies (Head et al., 2003).

\section{Ephexin}

The identification and characterization by Shamah et al. (2001) of the RhoGEF ephexin as a crucial component in retinal growth cone collapse was an important step toward further understanding the link between EphA receptors and the control of actin cytoskeleton dynamics by small GTPases. Activation of EphA (but not EphB) receptors switches the uniform affinity of ephexin for RhoA, Rac1, and Cdc42 toward RhoA, the activity of which is required for retinal growth cone collapse (Wahl et al., 2000). Ephexin is bound constitutively to EphA receptors, and it is not known which signal leads to the change of its specificity.

Ephexin is a target of SFKs, because expression of ephexin in fibroblast cells resulted in a robust ephexin tyrosine phosphorylation, which could be inhibited by PP2 (Fig. $8 B$ ). However, we do not know whether this modification induces a change in specificity for these Rho GTPases. Ephexin coimmunoprecipitates with EphA receptors from retinal lysates and co-migrates with the weakest of the $80 \mathrm{kDa}$ bands phosphorylated by SFKs (Figs. 7, $8 C$ ). Thus in chick retina our data suggest that a sustained tyrosine phosphorylation is not a prominent feature of ephexin. However, because it plays an important role in retinal growth cone repulsion, one would expect in this context that its tyrosine phosphorylation is kept at a rather low level in vivo and might occur only transiently during the activation of EphA receptors.

\section{SFKs tyrosine-phosphorylate EphA receptors}

Expression of the SFK member Fyn in SYF cells, which essentially are devoid of any SFK activity (Klinghoffer et al., 1999), results in a robust increase in tyrosine phosphorylation of the EphA receptor itself, which occurs on top of the activation achieved via ephrinA-induced receptor clustering and autophosphorylation (Fig. 6B). Thus it appears that, in addition to phosphorylating proteins bound to EphA receptors (e.g., cortactin and ephexin), SFKs may phosphorylate additional tyrosines on the EphA receptor itself and in doing so create additional binding sites for signaling molecules. An SFK-mediated increase in tyrosine phosphorylation of EphA receptors has not been reported so far, but other receptor tyrosine kinases, such as the EGF receptor (Biscardi et al., 1999), are known targets of SFK phosphorylation.

\section{The preference of nasal axons in the stripe assay after SFK inhibition}

The inhibition of SFKs after PP2 treatment or overexpression of Csk resulted unexpectedly in a slight gain of sensitivity of nasal axons to posterior tectal membranes in the stripe assay (Figs. 2, 4).

Currently, it is thought that, for guidance in the stripe assay, EphA signaling is required for temporal axons, whereas for nasal axons EphA signaling plus an element derived from the expression of ephrinAs is important (Knöll and Drescher, 2002). Although at present the nature of this ephrinA contribution to the behavior of nasal axons is speculative, it has been shown that ephrinAs can interfere with EphA receptor function, and this modulation might occur possibly on the basis of a nonreceptor function of ephrinAs, such as "masking," or a specific change in the pattern of tyrosine phosphorylation of EphAs or via a direct and rather special cis-interaction between EphAs and ephrinAs
(Connor et al., 1998; Hornberger et al., 1999). In addition to this, data from vomeronasal axons (Knöll et al., 2001) suggest the possibility of a receptor function of ephrinAs on retinal axons indicating interference between EphA and ephrinA signaling in nasal growth cones. With regard to this receptor function it has been shown that activation of ephrinA-expressing cells by soluble EphA-Fc resulted in an increased and SFK-dependent adhesion of these cells (Davy et al., 1999; Huai and Drescher, 2001). The SFK dependency is intriguing in view of the data obtained in this investigation, because inhibition of SFKs in the stripe assay would interfere not only with EphA receptor (forward) signaling but also with ephrinA (reverse) signaling. Potentially then, the abolition of both ephrinA and EphA signaling might cause the minor preference of nasal axons to grow on stripes from anterior tectum. This abolishment might lead to the activation of signaling pathways that otherwise are "hidden" behind the EphA/ephrinA signaling pathways. Alternatively, the slight preference might be explained by an increased adhesion of ephrinA-expressing nasal axons to those stripes that contain higher concentrations of EphAs, that is the anterior tectal membranes. Such an increased preference would not be obvious in ephrinA5 stripe assay experiments (Fig. 3) in which the stripes do not contain EphA receptors.

\section{Outlook}

Here we have shown data indicating an important role of SFKs in retinal axon guidance. However, SFK activity is controlled not only by Csk but also by ubiquitination, which targets SFKs for proteasome-mediated degradation (Harris et al., 1999). Because it has been reported recently that inhibition of proteasome function abolishes growth cone guidance (Campbell and Holt, 2001), it will be interesting to investigate whether growth cone guidance requires a constant turnover of SFKs (Robles et al., 2003), which, if blocked, also would abolish the guidance of retinal axons.

\section{References}

Abram CL, Courtneidge SA (2000) Src family tyrosine kinases and growth factor signaling. Exp Cell Res 254:1-13.

Beggs HE, Soriano P, Maness PF (1994) NCAM-dependent neurite outgrowth is inhibited in neurons from Fyn-minus mice. J Cell Biol 127:825-833.

Biscardi JS, Maa MC, Tice DA, Cox ME, Leu TH, Parsons SJ (1999) c-Srcmediated phosphorylation of the epidermal growth factor receptor on $\mathrm{Tyr}^{845}$ and $\mathrm{Tyr}^{1101}$ is associated with modulation of receptor function. J Biol Chem 274:8335-8343.

Blake RA, Broome MA, Liu X, Wu J, Gishizky M, Sun L, Courtneidge SA (2000) SU6656, a selective Src family kinase inhibitor, used to probe growth factor signaling. Mol Cell Biol 20:9018-9027.

Campbell DS, Holt CE (2001) Chemotropic responses of retinal growth cones mediated by rapid local protein synthesis and degradation. Neuron 32:1013-1026.

Cary LA, Cooper JA (2000) Molecular switches in lipid rafts. Nature 404:945-947.

Cheng HJ, Nakamoto M, Bergemann AD, Flanagan JG (1995) Complementary gradients in expression and binding of ELF-1 and MEK4 in development of the topographic retinotectal projection map. Cell 82:371-381.

Ciossek T, Monschau B, Kremoser C, Löschinger J, Lang S, Müller BK, Bonhoeffer F, Drescher U (1998) Eph receptor-ligand interactions are necessary for guidance of retinal ganglion cell axons in vitro. Eur J Neurosci 10:1574-1580.

Connor RJ, Menzel P, Pasquale EB (1998) Expression and tyrosine phosphorylation of Eph receptors suggest multiple mechanisms in patterning of the visual system. Dev Biol 193:21-35.

Cox EC, Müller B, Bonhoeffer F (1990) Axonal guidance in the chick visual system: posterior tectal membranes induce collapse of growth cones from the temporal retina. Neuron 2:31-37.

Davy A, Gale NW, Murray EW, Klinghoffer RA, Soriano P, Feuerstein C, Robbins SM (1999) Compartmentalized signaling by GPI-anchored ephrin-A5 requires the Fyn tyrosine kinase to regulate cellular adhesion. Genes Dev 13:3125-3135. 
Drescher U, Bonhoeffer F, Müller BK (1997) The Eph family in retinal axon guidance. Curr Opin Neurobiol 7:75-80.

Du Y, Weed SA, Xiong WC, Marshall TD, Parsons JT (1998) Identification of a novel cortactin SH3 domain-binding protein and its localization to growth cones of cultured neurons. Mol Cell Biol 18:5838-5851.

Ellis C, Kasmi F, Ganju P, Walls E, Panayotou G, Reith AD (1996) A juxtamembrane autophosphorylation site in the Eph family receptor tyrosine kinase, Sek, mediates high affinity interaction with p59 ${ }^{\text {fyn }}$. Oncogene 12:1727-1736.

Fan L, Di Ciano-Oliveira C, Weed SA, Craig AW, Greer PA, Rotstein OD, Kapus A (2004) Actin depolymerization-induced tyrosine phosphorylation of cortactin: the role of Fer kinase. Biochem J 380[Pt 2]:581-591.

Feldheim J, Kim Y-I, Bergemann AD, Frisén J, Barbacid M, Flanagan JG (2000) Genetic analysis of ephrin-A2 and ephrin-A5 shows their requirement in multiple aspects of retinocollicular mapping. Neuron 25:563-574.

Flanagan JG, Vanderhaeghen P (1998) The ephrins and Eph receptors in neural development. Annu Rev Neurosci 21:309-345.

Frame MC, Fincham VJ, Carragher NO, Wyke JA (2002) v-Src's hold over actin and cell adhesions. Nat Rev Mol Cell Biol 3:233-245.

Guan KL, Rao Y (2003) Signalling mechanisms mediating neuronal responses to guidance cues. Nat Rev Neurosci 4:941-956.

Hall A, Nobes CD (2000) Rho GTPases: molecular switches that control the organization and dynamics of the actin cytoskeleton. Philos Trans R Soc Lond B Biol Sci 355:965-970.

Hanke JH, Gardner JP, Dow RL, Changelian PS, Brissette WH, Weringer EJ, Pollok BA, Connelly PA (1996) Discovery of a novel, potent, and Src family-selective tyrosine kinase inhibitor. J Biol Chem 271:695-701.

Harris KF, Shoji I, Cooper EM, Kumar S, Oda H, Howley PM (1999) Ubiquitin-mediated degradation of active Src tyrosine kinase. Proc Natl Acad Sci USA 96:13738-13743.

Head JA, Jiang D, Li M, Zorn LJ, Schaefer EM, Parsons JT, Weed SA (2003) Cortactin tyrosine phosphorylation requires Racl activity and association with the cortical actin cytoskeleton. Mol Biol Cell 14:3216-3229.

Hornberger MR, Dutting D, Ciossek T, Yamada T, Handwerker C, Lang S, Weth F, Huf J, Wessel R, Logan C, Tanaka H, Drescher U (1999) Modulation of EphA receptor function by coexpressed ephrinA ligands on retinal ganglion cell axons. Neuron 22:731-742.

Howell BW, Cooper JA (1994) Csk suppression of Src involves movement of Csk to sites of Src activity. Mol Cell Biol 14:5402-5411.

Huai J, Drescher U (2001) An ephrinA-dependent signaling pathway controls integrin function and is linked to the tyrosine phosphorylation of a $120 \mathrm{kDa}$ protein. J Biol Chem 276:6689-6694.

Huang C, Ni Y, Wang T, Gao Y, Haudenschild CC, Zhan X (1997a) Downregulation of the filamentous actin cross-linking activity of cortactin by Src-mediated tyrosine phosphorylation. J Biol Chem 272:13911-13915.

Huang C, Tandon NN, Greco NJ, Ni Y, Wang T, Zhan X (1997b) Proteolysis of platelet cortactin by calpain. J Biol Chem 272:19248-19252.

Huang J, Asawa T, Takato T, Sakai R (2003) Cooperative roles of Fyn and cortactin in cell migration of metastatic murine melanoma. J Biol Chem 278:48367-48376.

Ignelzi Jr MA, Miller DR, Soriano P, Maness PF (1994) Impaired neurite outgrowth of Src-minus cerebellar neurons on the cell adhesion molecule L1. Neuron 12:873-884.

Imamoto A, Soriano P (1993) Disruption of the csk gene, encoding a negative regulator of Src family tyrosine kinases, leads to neural tube defects and embryonic lethality in mice. Cell 73:1117-1124.

Kapus A, Di Ciano C, Sun J, Zhan X, Kim L, Wong TW, Rotstein OD (2000) Cell volume-dependent phosphorylation of proteins of the cortical cytoskeleton and cell-cell contact sites. The role of Fyn and FER kinases. J Biol Chem 275:32289-32298.

Kawakatsu H, Sakai T, Takagaki Y, Shinoda Y, Saito M, Owada MK, Yano J (1996) A new monoclonal antibody which selectively recognizes the active form of Src tyrosine kinase. J Biol Chem 271:5680-5685.

Klinghoffer RA, Sachsenmaier C, Cooper JA, Soriano P (1999) Src family kinases are required for integrin but not PDGFR signal transduction. EMBO J 18:2459-2471.

Knöll B, Drescher U (2002) Ephrin-As as receptors in topographic projections. Trends Neurosci 25:145-149.

Knöll B, Zarbalis Z, Wurst W, Drescher U (2001) A role for the EphA family in the topographic targeting of vomeronasal axons. Development 128:895-906
Kullander K, Klein R (2002) Mechanisms and functions of Eph and ephrin signaling. Nat Rev Mol Cell Biol 3:475-486.

Lai KO, Ip FC, Cheung J, Fu AK, Ip NY (2001) Expression of Eph receptors in skeletal muscle and their localization at the neuromuscular junction. Mol Cell Neurosci 17:1034-1047.

McLaughlin T, Hindges R, O'Leary DD (2003) Regulation of axial patterning of the retina and its topographic mapping in the brain. Curr Opin Neurobiol 13:57-69.

Menzel P, Valencia F, Godement P, Dodelet VC, Pasquale EB (2001) Ephrin-A6, a new ligand for EphA receptors in the developing visual system. Dev Biol 230:74-88.

Monschau B, Kremoser C, Ohta K, Tanaka H, Kaneko T, Yamada T, Handwerker C, Hornberger MR, Löschinger J, Pasquale EB, Siever DA, Verderame MF, Müller BK, Bonhoeffer F, Drescher U (1997) Shared and distinct functions of RAGS and ELF-1 in guiding retinal axons. EMBO J $16: 1258-1267$.

Morse WR, Whitesides 3rd JG, LaMantia AS, Maness PF (1998) p59 fyn and pp $60^{\text {c-src }}$ modulate axonal guidance in the developing mouse olfactory pathway. J Neurobiol 36:53-63.

Nada S, Yagi T, Takeda H, Tokunaga T, Nakagawa H, Ikawa Y, Okada M, Aizawa S (1993) Constitutive activation of Src family kinases in mouse embryos that lack Csk. Cell 73:1125-1135.

Nakagawa T, Tanaka S, Suzuki H, Takayanagi H, Miyazaki T, Nakamura K, Tsuruo T (2000) Overexpression of the csk gene suppresses tumor metastasis in vivo. Int J Cancer 88:384-391.

Raper JA, Kapfhammer J (1990) The enrichment of a neuronal growth cone collapsing activity from embryonic chick brain. Neuron 4:21-29.

Robles E, Huttenlocher A, Gomez TM (2003) Filopodial calcium transients regulate growth cone motility and guidance through local activation of calpain. Neuron 38:597-609.

Shamah SM, Lin MZ, Goldberg JL, Estrach S, Sahin M, Hu L, Bazalakova M, Neve RL, Corfas G, Debant A, Greenberg ME (2001) EphA receptors regulate growth cone dynamics through the novel guanine nucleotide exchange factor ephexin. Cell 105:233-244.

Stein PL, Vogel H, Soriano P (1994) Combined deficiencies of Src, Fyn, and Yes tyrosine kinases in mutant mice. Genes Dev 8:1999-2007.

Suetsugu S, Hattori M, Miki H, Tezuka T, Yamamoto T, Mikoshiba K, Takenawa T (2002) Sustained activation of N-WASP through phosphorylation is essential for neurite extension. Dev Cell 3:645-658.

Takasu MA, Dalva MB, Zigmond RE, Greenberg ME (2002) Modulation of NMDA receptor-dependent calcium influx and gene expression through EphB receptors. Science 295:491-495.

Thomas SM, Brugge JS (1997) Cellular functions regulated by Src family kinases. Annu Rev Cell Dev Biol 13:513-609.

Vindis C, Cerretti DP, Daniel TO, Huynh-Do U (2003) EphB1 recruits c-Src and $\mathrm{p} 52^{\text {shc }}$ to activate MAPK/ERK and promote chemotaxis. J Cell Biol 162:661-671.

Wahl S, Barth H, Ciossek T, Aktories K, Mueller BK (2000) Ephrin-A5 induces collapse of growth cones by activating Rho and Rho kinase. J Cell Biol 149:263-270.

Walter J, Kern-Veits B, Huf J, Stolze B, Bonhoeffer F (1987) Recognition of position-specific properties of tectal cell membranes by retinal axons in vitro. Development 101:685-696.

Weaver AM, Karginov AV, Kinley AW, Weed SA, Li Y, Parsons JT, Cooper JA (2001) Cortactin promotes and stabilizes Arp2/3-induced actin filament network formation. Curr Biol 11:370-374.

Weed SA, Parsons JT (2001) Cortactin: coupling membrane dynamics to cortical actin assembly. Oncogene 20:6418-6434.

Weed SA, Du Y, Parsons JT (1998) Translocation of cortactin to the cell periphery is mediated by the small GTPase Rac1. J Cell Sci 111[Pt 16]:2433-2443.

Weinl C, Drescher U, Lang S, Bonhoeffer F, Loschinger J (2003) On the turning of Xenopus retinal axons induced by ephrin-A5. Development 130:1635-1643.

Wilkinson DG (2000) Topographic mapping: organizing by repulsion and competition? Curr Biol 10:R447-R451.

Wong EV, Kerner JA, Jay DG (2004) Convergent and divergent signaling mechanisms of growth cone collapse by ephrinA5 and slit2. J Neurobiol 59:66-81.

Worley T, Holt C (1996) Inhibition of protein tyrosine kinases impairs axon extension in the embryonic optic tract. J Neurosci 16:2294-2306.

Zisch AH, Kalo MS, Chong LD, Pasquale EB (1998) Complex formation between EphB2 and Src requires phosphorylation of tyrosine 611 in the EphB2 juxtamembrane region. Oncogene 16:2657-2670. 